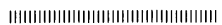

\title{
Accelerator Mass Spectrometry (AMS)の生化学分野への応用
}

\author{
宮 下 正 弘* \\ 京都大学大学院農学研究科応用生命科学専攻
}

(平成 13 年 11 月 20 日受理)

\section{Applications of Accelerator Mass Spectrometry (AMS) to Biochemical Studies}

\author{
Masahiro MiYASHITA \\ Division of Applied Life Sciences, Graduate School of Agriculture, Kyoto University, Kyoto 606-8502, Japan
}

Key words: accelerator mass spectrometry, dermal exposure, radioimmunoassay, protein sequencing.

\section{は じめに}

femto (f, フェムト), atto (a, アト), zepto (z, ゼプト) という言葉はあまり聞き慣れないという人が多いかもしれ

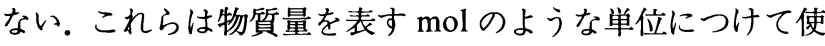
われる接頭語で，それぞれ $10^{-15}, 10^{-18}, 10^{-21}$ を意味する. 聞き慣れないのも当然で, 通常, 特に生化学の研究におい てこのような小さい值を用いることは稀である．微量物質 を検出するための様々な方法がこれまで開発されてきた が，その中で，比較的このような超微量に出くわすのは質 量分析 (MS) による研究であろう. MS は物質の分子量と いう基本的な物性デー夕を与える有用な分析法として古く から広く用いられてきた. 当初, MS はそのイオン化法の性 質上，低分子有機化合物の構造決定に広く用いられた。近 年ではエレクトロスプレーイオン化法に代表されるソフト なイオン化法が確立され，タンパク質のような生体高分子 の分析まで可能になったことから，生化学領域においても 必須の分析装置となってきた. MSの技術の発展が, 現在盛 んに行われているプロテオーム解析を推し進める原動力と なっていることは言うまでもない.MS の感度は他の分析 手法と比較しても高いものであり, fmol から amolレベル という超微量まで検出が可能になってきている.

\footnotetext{
* $=$ 606-8502 京都府京都市左京区北白川追分町

E-mail: miyamasa@ kais.kyoto-u.ac.jp
}

Accelerator Mass Spectrometry（AMS）は一般的にはあま り知られていない特殊な装置であるが，その名の通り加速 器 (Accelerator) を持つ質量分析計である1). 質量分析計と いう名が付いてはいるが，一般的な質量分析とは異なり， 「分子量」を測定することはできない．AMS では分子を構 成する，ある特定の「元素」の同位体の量のみを精密に測 定する. 代表的な測定元素である ${ }^{14} \mathrm{C}$ の場合, 従来の質量分 析法では， ${ }^{14} \mathrm{C}$ とほとんど質量が同じである ${ }^{13} \mathrm{CH}$ や ${ }^{12} \mathrm{CH}_{2}$ などを区別することができないため， ${ }^{14} \mathrm{C}$ だけを特異的に 測定することは不可能であった。 それに対し, AMS では加 速器をはじめとした，妨害イオンを除去する様々な工夫に より，ノイズとなるバックグラウンドをほとんど排除でき る. その結果として，元素の同位体，特にその自然存在比 が極めて低い放射性同位体を高感度で測定することが可能 となった. AMSによって測定可能な主な同位体元素を表 1 に挙げた.この中では, ${ }^{14} \mathrm{C}$ が測定の対象になることが最も 多い，考古学研究における年代測定や，地球環境解析にお ける ${ }^{14} \mathrm{C}$ 濃度測定など, 主に微量試料から高精度に同位体 比を測定する必要のある目的に用いられ，これまでは得る ことのできなかった多くの情報がもたらされている.

近年, 米国ローレンス・リバーモア国立研究所 (LLNL) のグループを中心として，AMS の最大の利点である高感 度を生かすべく, 生化学分野への応用が試みられている2。 生化学分野において, 化合物の挙動を知るためにしばし 


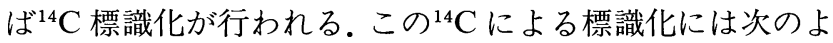
うな利点が考えられる。一つは，ほとんどの化学物質は炭 素を含んでおり ${ }^{14} \mathrm{C}$ で標識化しても，構造に変化を与えな いこと. 二つ目は， ${ }^{14} \mathrm{C}$ が地球上において比較的少なく，， イズとなるバックグラウンドが低いことである。また， ${ }^{14} \mathrm{C}$ は半減期が長いため, 長期に渡って保存可能であることも, その利点であろう．長い半減期を持つ ${ }^{14} \mathrm{C}$ の比放射活性は 低く, 通常用いられる液体シンチレーションカウンター （LSC）による測定にとっては不利であるが，AMS は原子 そのものの量を“直接的”に測定するので, ${ }^{14} \mathrm{C}$ の長い半減 期は測定に影響しない。つまり，AMS では崩壊数ではな く,質量数を 14 に固定して選択イオンモニタリング測定す

表 1 AMS によって測定できる主な同位体元素

\begin{tabular}{cccl}
\hline 同位体 & $\begin{array}{c}\text { 半減期 } \\
\text { (年) }\end{array}$ & $\begin{array}{c}\text { 感度 } \\
\left(\text { parts per } 10^{15}\right)\end{array}$ & $\begin{array}{c}\text { イオン源での } \\
\text { 試料の形 }\end{array}$ \\
\hline${ }^{3} \mathrm{H}$ & 12.3 & 0.1 & $\mathrm{TiH}_{2}$ \\
${ }^{10} \mathrm{Be}$ & $1.6 \times 10^{6}$ & 5 & $\mathrm{BeO}$ \\
${ }^{14} \mathrm{C}$ & 5730 & 2 & グラファイト \\
${ }^{26} \mathrm{Al}$ & 720,000 & 3 & $\mathrm{Al}_{2} \mathrm{O}_{3}$ \\
${ }^{36} \mathrm{Cl}$ & 300,000 & 5 & $\mathrm{AgCl} \mathrm{CaF}_{2}, \mathrm{CaH}_{2}$ \\
${ }^{41} \mathrm{Ca}$ & 105,000 & 2 & $\mathrm{AgI}^{129} \mathrm{I}$ \\
\hline
\end{tabular}

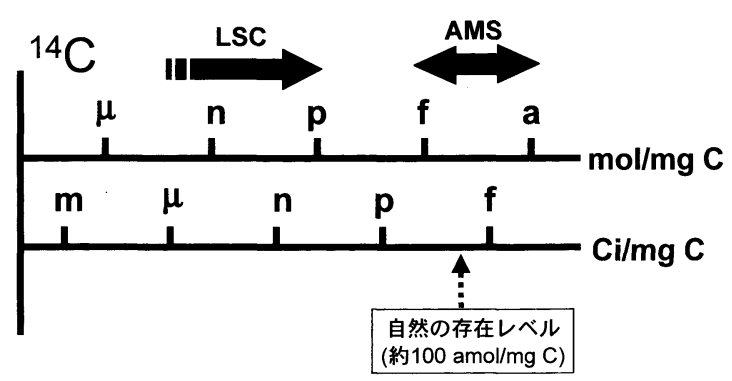

図 1 AMS と $\mathrm{LSC} の{ }^{14} \mathrm{C}$ 測定感度の比較
ると考えていただけばよい。図 1 に示したように，感度の 点では AMS は LSC に比べはるかに高く, ${ }^{14} \mathrm{C}$ 標識化合物 の高感度検出が可能である.このことは，これまでLSCで 行っていた多くの生化学研究に対して, AMS を応用する ことが可能であることを意味している.また, AMS は法律 的には放射性物質とは言えないレベルで検出を行うため, 測定後に放射性廃棄物が出ないという実際上の利点もあ る. 本解説においては, AMS の生化学分野への応用例とし て, LLNLのJ. S. Vogel らとカリフォルニア大学デービス 校の B. D. Hammock らのグループによって行われた研究 について紹介する。

\section{Accelerator Mass Spectrometry (AMS) の原理}

LLNLにおけるAMS の装置の概略を図 2 に示した。こ こでは ${ }^{14} \mathrm{C}$ の測定を例に挙げて，その測定原理を説明する. 測定試料は多く場合そのままの状態で測定することはでき ず，試料を燃焼によって $\mathrm{CO}_{2}$ の形にした後，還元してグラ ファイトにする必要がある.イオン源にセットされた試料 はセシウムイオンビームの照射により陰イオンとして放出 される. 生じた陰イオンは通常の磁場型質量分析計と同様 の手法により質量数 14 のみが選択される。このとき，内部 標準となる ${ }^{13} \mathrm{C}$ を測定するために質量数 13 もごく短時間 だけ選択される。この段階では ${ }^{14} \mathrm{C} に$ 加えて, ほとんど質量 数の変わらない ${ }^{13} \mathrm{CH}$ や12 $\mathrm{CH}_{2}$ なども含まれている。これら の妨害イオンを含む陰イオンは続いて加速器に導入され る. AMSには様々な種類の加速器が用いられているが, 図 2 に示したようなタンデム Van de Graaff 型加速器が最も 多く用いられている。この加速器は中央部分で高電圧 (2〜 $10 \mathrm{MV})$ で正に荷電しており,陰イオンは中央に向かって引 きつけられ加速される.中央部分には炭素薄膜が存在し, 陰 イオンはこれに衝突することによって電子がはぎ取られ， 陽イオン $\left(\mathrm{C}^{1+} \sim \mathrm{C}^{6+}\right)$ へと変換される.この際, ${ }^{13} \mathrm{CH}$ や ${ }^{12} \mathrm{CH}_{2}$

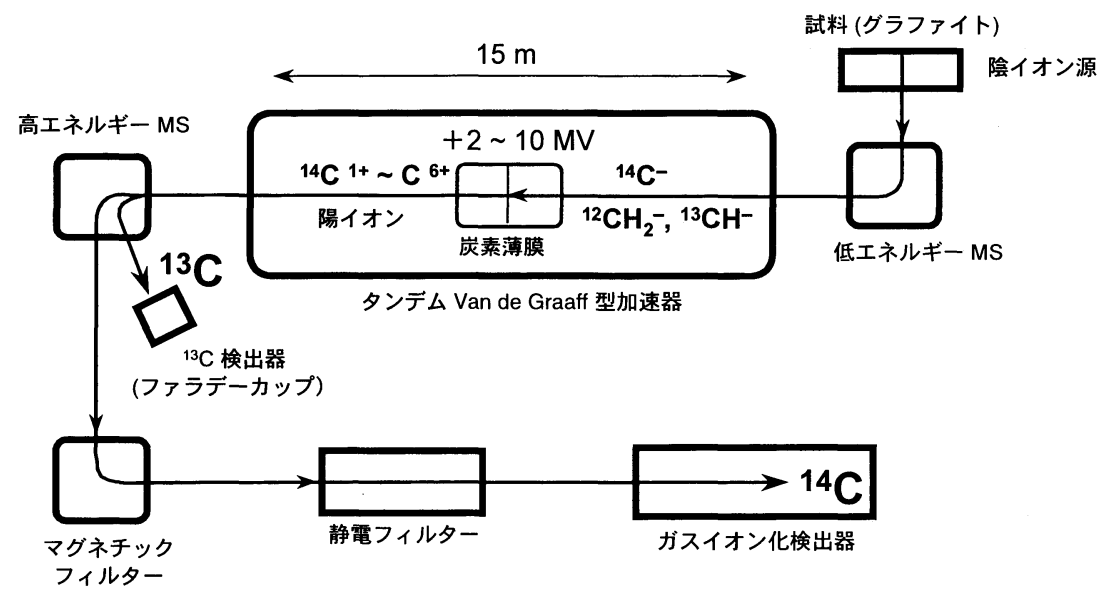

図 2 LLNLにおけるAMS の概略 
などの分子イオンは結合が切断されて原子イオンとなるこ とで妨害イオンではなくなる. ${ }^{14} \mathrm{C}\left(\right.$ 主に $\left.{ }^{14} \mathrm{C}^{4+}\right)$ は, さらにマ グネチックおよび静電フィルターを通った後, 最終的にガ スイオン化検出器によって測定される. AMS では ${ }^{14} \mathrm{C}$ の絶 対量は測定できないので, 同じ試料に含まれる ${ }^{13} \mathrm{C}$ を内部 標準として用いている。 ${ }^{13} \mathrm{C} の$ 量は加速器を出た後ファラ デーカップによって測定され, ${ }^{14} \mathrm{C} /{ }^{13} \mathrm{C}$ として測定值が得 られる. サンプルに含まれる全炭素の量が分かっていれば ${ }^{13} \mathrm{C}$ の量は決まるので, ${ }^{14} \mathrm{C}$ の量を決定することができる. 測定感度は極めて高く, 1 サンプルあたり $1 \mathrm{amol} \sim 10 \mathrm{fmol}$ （およそ $0.0001 \mathrm{dpm} \sim 1 \mathrm{dpm}$ )の ${ }^{14} \mathrm{C}$ を定量することが可能 である(図 1). ${ }^{14} \mathrm{C}$ は現在の地球上の生物圈では $1 \mathrm{mg}$ の炭 素中に約 $100 \mathrm{amol}$ 含まれている. そのため, amol レベルで 測定を行う場合は特にコンタミネーションの防止に細心の 注意を払う必要がある。ちなみに, 多くの試薬類は石油を原 料として作られており， ${ }^{14} \mathrm{C}$ ほとんど含まない“Dead Carbon”からなっているので, 測定にはほとんど影響しない.

\section{2. ヒトによる農薬の吸収・代謝・排出の研究}

農家のような農薬散布を頻繁に行う人にとって, 生体異 物である農薬の皮膚あるいは呼吸を通した吸収による健康 への影響は重大な関心事である。しかしながら，農薬がど れくらい皮膚を通して吸収され，どのように代謝されるの かについては, ヒトに対して実験を行うことが難しいため, 分からないことが多い，一般的に生体異物の吸収・代謝・ 排出の研究には放射性同位体で標識化した化合物が用いら れ，その検出には LSC が用いられる. LSC で検出するには 比較的高濃度で化合物を投与する必要があり, 実際にヒト を用いたこのような実験は，人体に対する化合物自身の毒 性や放射能による悪影響などの問題があり容易に行うこと ができない．また，放射性廃棄物などの実際上の問題もあ る. 動物を用いて同椂の実験を行うことは可能であるが, 必ずしもそこから得られた情報が七トに対して適用できる わけではなく，ヒトを用いて健康に影響しない濃度でこう いった実験が行えることが望ましい. AMS は LSCに比べ はるかに高感度であり，用いる放射能の量を極端に減らす ことが可能である。つまり人体に悪影響を及ぼさない量で ヒトを用いて実験を行うことができる.

アトラジン (図 3) は世界で最も使用された除草剤の一つ であり，その毒性は低いとされているが，七トに対する影 響はいまだ不明な点が多い。ヒトにおけるアトラジンの皮 膚からの吸収・代謝を詳細に調べるために, ${ }^{14} \mathrm{C}$ 標識アトラ ジンを用いた実験が行われた3)。この研究では，まずLSC と AMS の感度の比較が行われた．比較的多い量の標識化 合物（一人当たり $6.45 \mu \mathrm{Ci}$ あるいは $24.7 \mu \mathrm{Ci}$ ）が投与され ているが,これは LSC で測定できる最低限の放射性同位体 の量である．AMSのみを測定に用いる場合， $500 \mathrm{nCi} に ま$<smiles>CCNc1nc(Cl)nc(NC(C)C)n1</smiles><smiles>Clc1cc2c(cc1Cl)Oc1cc(Cl)c(Cl)cc1O2</smiles>

目 3 アトラジンおよびTCDD の構造

で減らすことが可能であり, 経口あるいは静注投与ではさ らに $100 \mathrm{nCi}$ にまで減らすことができる。この程度の放射 性同位体による被曝量は, 数時間の飛行機旅行で浴びる宇 宙線による被曝量とあまり変わらない。

健康なボランティアのヒトに対し所定の量の標識化合物 を皮虐上から 24 時間にわたって投与し続け,一定時間毎の 尿中に排出される ${ }^{14} \mathrm{C}$ の量が LSC または AMSによって測 定された。その結果，7 日間にわたる LSC と AMSによる 定量は非常に良く一致したが, 吸収および排出の量は, 動 物実験などからの予測よりは低いものであった。また，測 定感度を比較すると, AMS は LSCに比へ，濃度にして 12 倍, 物質量にして 1 万倍もの低い検出限界を有していた。 さらに，尿中における代謝物の同定が， HPLC 分析上にお ける標品との比較により行われた。この研究で用いられた 標識化合物の量は, 尿中の全放射能を LSCによって測定で きる限界に設定されたので，HPLCによる分離後の個々の フラクションの ${ }^{14} \mathrm{C}$ 量はもはや LSC では定量することは できなかった。一方, AMS では HPLCによる分離後も各フ ラクションの ${ }^{14} \mathrm{C}$ の定量が可能であった. また, HPLC 分析 の際, 標品は ${ }^{14} \mathrm{C}$ をほとんど含んでいないので, 試料と同時 にインジェクションすることが可能であり, UV 検出と AMS による検出を比較することで各ピークを容易に同定 することができたこのように，AMSを用いることによ ク，人体に対して悪影響を与えない濃度で，七トを用いて 生体異物の吸収・代謝・排出についての研究を行うことが 可能であることが示された，同様の手法はもちろん，栄養 素や医薬品の体内動態研究にも応用可能であり, いくつか の例が既に報告されている4).イギリスにある CBAMS (The Center for Biomedical Accelerator Mass Spectrometry) Ltd. では受託測定を始めており，今後 AMS を用いた薬物 動態研究の例は增えていくであろう.

\section{AMS を用いたラジオイムノアッセイ}

抗原抗体反応を利用したイムノアッセイは様々な分野に 
おいて用いられている重要な分析手法である，最近では， 狂牛病の病原体の検出に使われていることで，一般の人に も広く知られるようになってきた。開発初期におけるイム ノアッセイでは放射性同位体によって標識された抗原ある いは抗体を用いるラジオイムノアッセイが盛んに行われ

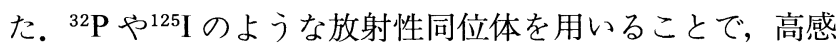
度の検出が行えるが，半減期が短かいため標識体が長期保 存できないという問題があった.一方, 放射性同位体によっ て抗原を標識する場合, ${ }^{14} \mathrm{C}$ や ${ }^{3} \mathrm{H}$ などは抗原の構造を変え ることなく導入が可能であるため，より直接的に抗原と抗 体との相互作用が測定できる。しかし，これらの同位体は 比較的半減期が長いため, LSC による測定では検出感度が あまり良くないという問題がある。また放射性同位体を用 いた実験を行える場所は限定されており，放射性廃棄物な どの問題もあって，現在ではラジオイムノアッセイに代 わって酵素標識による方法（ELISA 法など）が用いられる ことがほとんどである.しかしながら $\mathrm{AMS}$ は ${ }^{14} \mathrm{C}$ を高感度 に検出することができるため，これまでの ${ }^{14} \mathrm{C}$ 標識化合物 を用いたラジオイムノアッセイの欠点である, 感度の問題 を克服することができる，この考えに基づいて，農薬のア トラジン，ダイオキシン類の TCDD (図 3) に対寸る AMS を用いたラジオイムノアッセイが検討された5).

まず， ${ }^{14} \mathrm{C}$-アトラジン $(17.7 \mathrm{mCi} / \mathrm{mmol})$ に対する検量線 が AMS 測定により求められた。その結果, AMSによる定 量は 3 桁以上に渡って直線性を有しており，定量限界はわ

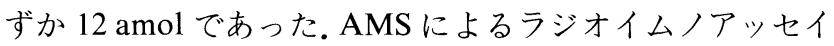
の方法の概略を図 4 に示したが，一つの反応にはアトラジ ン，TCDD はそれぞれわずか $0.24 \mathrm{pC}(80.53 \mathrm{dpm})$ が用い られるのみである。もちろん，この量は LSC では検出不可 能であり，放射性廃棄物としての基準以下である. AMS を 用いてアトラジン, TCDD のラジオイムノアッセイが行わ れた結果，検出感度が ELISA 法と比較して 10 倍程度向上 した.この検出感度は, 抗体の Kd 值から推測される理論值 に近く，AMS を用いるラジオイムノアッセイが非常に優 れていることを示している，酵素標識法によってもある程 度高感度なイムノアッセイを構築することは可能である が，様々な抗原と抗体との組み合わせを試す必要がある。

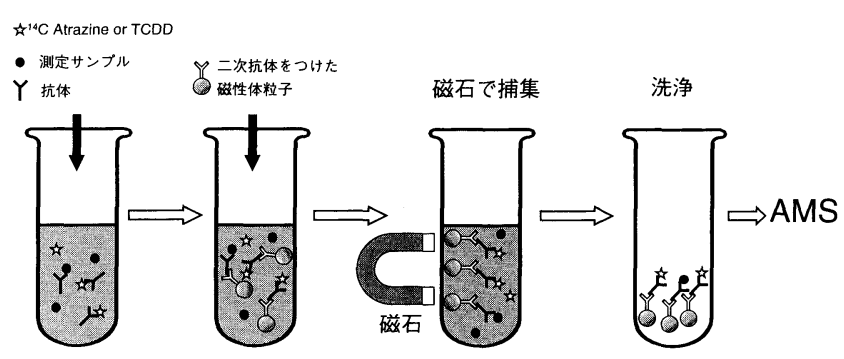

図4 AMS を用いたラジオイムノアッセイの方法の概略
一方, AMS を用いるラジオイムノアッセイでは, 標識抗原 は ${ }^{14} \mathrm{C}$ を含む以外は測定対象となる化合物と同じ構造であ るため, このような最適化が必要ではなく，その感度は抗 体の性質によってのみ決まる。このように, AMS を用いる イムノアッセイは，これまでにない感度が得られるだけで なく，シンプルに実験系を構築できることや，放射性廃棄 物を出さないといった点においても優れた方法であること が示された，AMS を用いる方法では， ${ }^{14} \mathrm{C}$ 標識化合物を合 成しなければならないという問題がある。しかしながら， 対象となる農薬などは一般的にその開発段階で, 代謝実験 などの目的で標識体が合成されることが多く, 標識化の方 法については詳細に検討されている場合が多い.

\section{4. 超高感度タンパク質シークエンシング}

様々な生物のゲノム解析が行われ, デー夕が蓄積しつつ ある現在，その次の段階として遺伝子の翻訳によってでき るタンパク質の網羅的解析（プロテオーム解析）に関心が 持たれている.プロテオーム解析においてはタンパクは二 次元電気泳動などの技術によって分離された後, 個及のス ポットはエドマン分解法や MS を駆使してそのアミノ酸配 列が決定される。こういった研究では, 八イスループット が何よりも重要であるため, 比較的高感度 ( fmol オーダー) かつ迅速に配列が得られる, MS を用いたアミノ酸配列決 定法が主に用いられる。しかしながら，この方法は等しい 質量数を有するイソロイシンとロイシンや，ほぼ等しいグ ルタミンとリジンを区別することができないという久点が あり, 新規なタンパク質の解析に用いることは困難である。 一方，エドマン分解法は最も確立されたアミノ酸配列決定 法であり，広く用いられてきたものの, MS 法に比へ感度が 低く, 通常の分析では pmol オーダーの試料を要する. 感度 については, エドマンによる発明以降様々な工夫が行われ， その向上が図られてきた。中でも, エドマン分解反応（図 5)によって得られる PTH-アミノ酸の検出を, UV 検出器 を装備した HPLC 法で行えるようになって格段に感度が 上昇した。現在のシステムは基本的には 20 年ほど前のこの 段階とほとんど同じである。その後の改良はゆっくり進み， 現在では数百 fmolの試料の解析が可能となってきている が, 感度の面では MS 法に大きく水をあけられた感がある。 エドマン分解法の改良の歴史の中で，PTH-アミノ酸の 検出感度を上げるために放射性同位体 $\left({ }^{14} \mathrm{C},{ }^{3} \mathrm{H},{ }^{35} \mathrm{~S}\right)$ によ る標識エドマン試薬 (phenyl isothiocyanate, PITC) が用い られたことがあった。この方法は, 当時としては高感度で あったが, その後の HPLC の導入により感度の面だけでな く，簡便さに扔いても劣るため用いられなくなった。しか しながら, AMS を検出器として用いることにより, 放射性 同位体標識したPTH-アミノ酸を極めて高感度に検出でき るとの考えのもと，すべてのアミノ酸を ${ }^{14} \mathrm{C}$ 標識したタン 
パク質を用いてその検討が行われた ${ }^{6}$ (図 6-A). ${ }^{14} \mathrm{C}$ 標識化 タンパク質は大腸菌を用いた発現系において合成された。

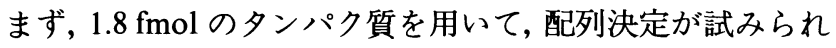
た。この量は従来のエドマン分解法では分析不可能な量で あることは言うまでもないが, MS 法においても困難であ る. エドマン分解を 10 サイクル行い，それぞれ得られた PTH-アミノ酸をHPLCによって分離し, AMS 測定を行っ

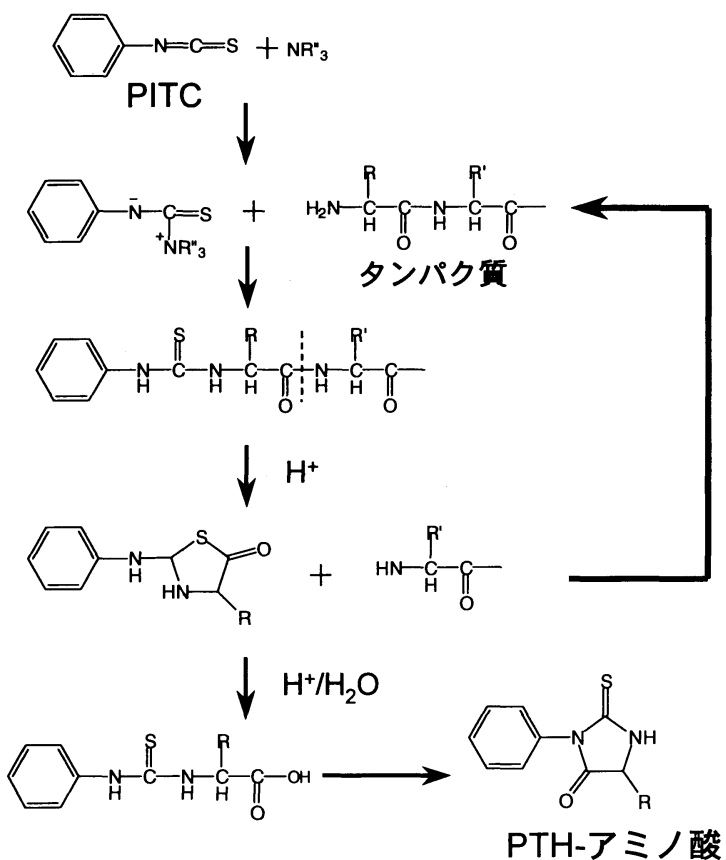

図 5 エドマン分解反応

A) UV検出による覆準PTH-アミノ酸涅合物のHPLC分析

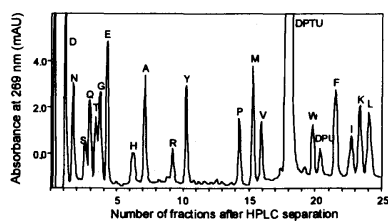

B) AMS测定によるPTH-アミノ酸の同定

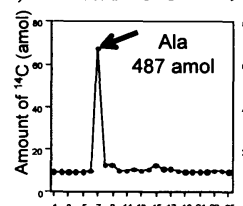

Cycle 1

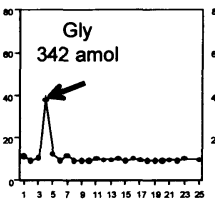

Cycle 2

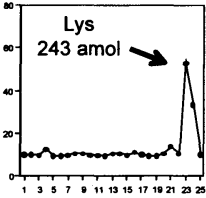

Cycle 3

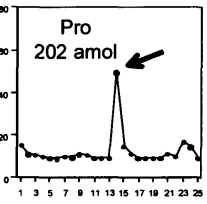

Cycle 4
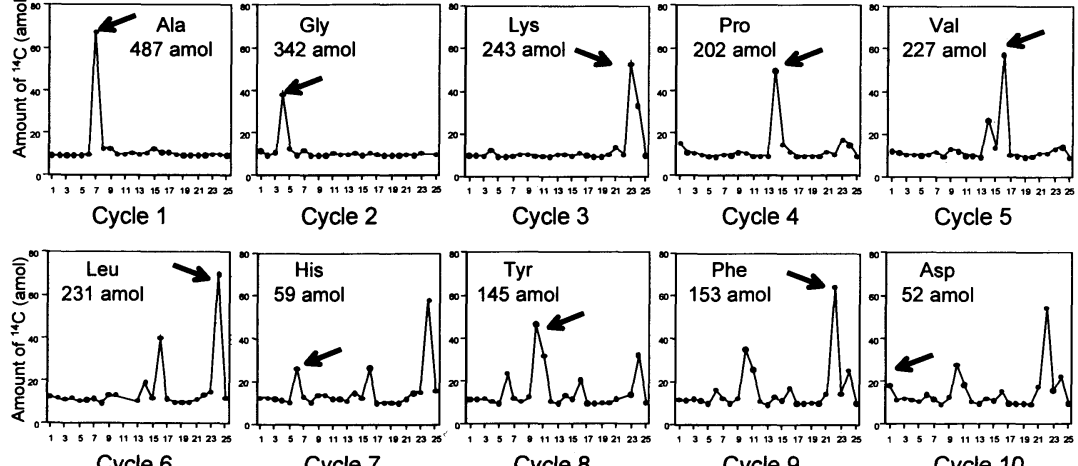

Cycle 7
た。 その結果, $\left[{ }^{14} \mathrm{C}\right] \mathrm{PTH}-ア ミ ノ$ 酸由来の HPLC ピークに のみ ${ }^{14} \mathrm{C}$ が観測され，10 残基の $\mathrm{N}$ 末端配列を同定すること ができた（図 7).UV 検出の場合，溶媒を含め，様及なも のに由来する UV 吸収性物質が解析の邪魔をすることが 多いが，AMSによる ${ }^{14} \mathrm{C}$ 測定の場合，極めてバックグラウ ンドのノイズが低く，容易にピークを同定することができ た. また, タンパク質の微量分析の場合, 試料が器壁に吸 着するなどしてほとんど失われてしまう場合がある。ここ では，それを防ぐため大過剩の非標識タンパク質が試料の 希釈の段階から添加されている. AMSによる測定ではこ $の^{14} \mathrm{C}$ 非標識のタンパク質は測定に影響しない。このよう な工夫により，反復収率も $88 \%$ とまずまずの結果であった。 実際，試料を希釈する際に非標識タンパク質を入れなかっ

A) ${ }^{14} \mathrm{C}$ 標識化 タンパク犋を用いる方法

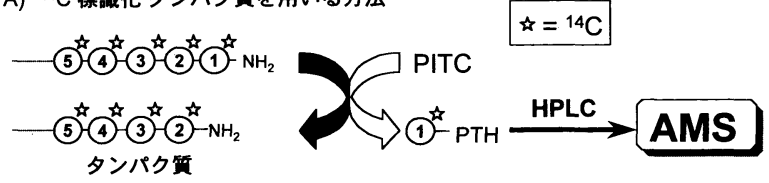

B) ${ }^{14} \mathrm{C}$ 標識化 PITCを用いる方法

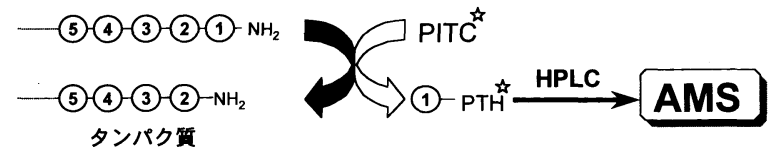

困 6 AMS を検出器に用いたエドマン分解によるアミノ 酸配列決定法

A) ${ }^{14} \mathrm{C}$ 標識化タンパク質を用いる方法. B) ${ }^{14} \mathrm{C}$ 標識化 PITC を用いる方法.

図 $71.76 \mathrm{fmol}$ の $^{14} \mathrm{C}$ 標識化タンパク質を用いたエドマン分解反応後の PTH-アミノ酸の AMSによる同定 A）標準 PTH-アミノ酸混合物の UV 検出による HPLC 分析. B) AMS による HPLC フラクションの ${ }^{14} \mathrm{C}$ 量の測定結果. 矢印は 同定されたアミノ酸のピークを示し、数值は ${ }^{14} \mathrm{C}$ の量から計算された収量を表す。 
た場合，大幅なシグナルの減少が見られた。さらに，amol

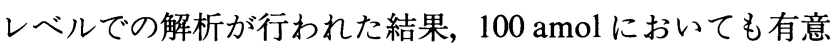
にHPLCピークが観測され，AMS を用いたエドマン分解 法が amol レベルにおいてもアミノ酸配列を決定できるこ とが示された。ここで述べた配列決定法は，タンパク質を ${ }^{14} \mathrm{C}$ で標識する必要があるため，限られた状況でしか用い ることができない，さらに適用範囲を広げ，一般的な方法 となるにはタンパク質ではなくエドマン試薬（PITC）を ${ }^{14} \mathrm{C}$ 標識する必要がある. 図 6-Bに示したように, ${ }^{14} \mathrm{C}$ 標識 化 PITC を用いることでも同様に $\left[{ }^{14} \mathrm{C}\right] \mathrm{PTH}-ア ミ ノ$ 酸が得 られ，AMS で検出することが可能となるであろう。

微量のタンパク質の量を正確に定量することもまた難し い. AMSによる ${ }^{14} \mathrm{C}$ の検出は高感度であるだけでなく，定 量的でもある点を生かし，微量タンパク質の定量に用いる 試みも行われている7).タンパク質の研究では，より高感度 な微量分析技術が求められており，AMS は今後このよう な分野でも多く用いられるであろう.

\section{おわりに}

AMS の最大の特徵である定量性と高感度を生かした研 究例について述べてきたが，これらの例がもっと一般的に なるには越えなければならないハードルはいくつかある. まず，AMS が巨大な装置であることが挙げられる.図 1 に も示したように, LLNLの AMS は加速器だけで 15 メート ルもの長さを有しており，装置全体を含めると，体育館ほ どの広さが必要となってくる.また，ほとんどの AMS は特 注であり，その製造コストは莫大である，実際，LLNLの もので約 700 万ドル $(\$ 1=¥ 120$ として 8 億 4 千万円）もの 巨額の費用を必要とした。しかしながら，これらの問題は 技術の進歩と需要の増加により克服されるものであろう. 現在，LLNL では生医化学分野専用の小型 AMS が稼働し つつある.ほとんどの生医化学分野での測定は, ${ }^{14} \mathrm{C}$ を用い るので, これに限定することでこれまでの装置の 12 分の 1 にまで小型化が可能となり，製造コス卜も従来の装置より も大幅に削減されている，今後，装置の設置面積が現在の NMR ぐらいになり，価格が 1 億円を下回るようになれば， AMS を導入する研究機関は増えていくであろう.

AMS が一般的な測定装置となるには，もう一つ越えな ければならない障壁がある. ${ }^{14} \mathrm{C}$ の測定の際, 試料はそのま まの状態では用いることができず，あらかじめグラファイ トにしておく必要がある。この作業は経験を要するだけで なく, 時間もかかるものであり, 測定の効率化のボトルネッ クとなっている。ここで例に挙げた研究においても, HPLC による分離の後, 各フラタションを個々にグラファイト化 し，測定を行っている。もし，このような試料調製を自動 化できたり，HPLCやGCによる分離後，直接試料を AMS に導入することができれば，より一層の測定の効率化が図
れるであろう．現在，この問題に対処すべく新たな装置の 設計・改良が進められている8).

最近の様々な検出手法の改良や発明により，amol オ一 ダーという超微量での測定がかなり身近なものとなってき た. $1 \mathrm{~mol}$ は $6.02 \times 10^{23}$ 個の原子・分子を指すが， $1 \mathrm{amol}$ で は $6.02 \times 10^{5}$ 個に相当する. 今後さらに測定感度の向上が進 むと, mol ではなく分子の数で言い表すほうが分かりやす い時代が訪れるであろう。

\section{引 用 文 献}

1) (a) L. K. Fifield: Rep. Prog. Phys. 62, 1223-1274 (1999) (b) J. S. Vogel, K. W. Turteltaub, R. Finkel \& D. E. Nelson: Anal. Chem. 67, A353-A359 (1995)

2) (a) J. S. Felton, K. W. Turteltaub, J. S. Vogel, R. Balhorn, B. L. Gledhill, J. R. Southon, M. W. Caffee, R. C. Finkel, D. E. Nelson, I. D. Proctor \& J. C. Davis: Nucl. Instrum. Meth. Phys. Res. B 52, 517-523 (1990)

(b) K. W. Turteltaub, J. S. Felton, B. L. Gledhill, J. S. Vogel, J. R. Southon, M. W. Caffee, R. C. Finkel, D. E. Nelson, I. D. Proctor \& J. C. Davis: Proc. Nat. Acad. Sci. USA 87, 5288-5292 (1990)

3) (a) S. D. Gilman, S. J. Gee, B. D. Hammock, J. S. Vogel, K. Haack, B. A. Buchholz, S. Freeman, R. C. Wester, X. Y. Hui \& H. I. Maibach: Anal. Chem. 70, 3463-3469 (1998) (b) B. A. Buchholz, E. Fultz, K. W. Haack, J. S. Vogel, S. D. Gilman, S. J. Gee, B. D. Hammock, X. Hui, R. C. Wester \& H. I. Maibach: Anal. Chem. 71, 3519-3525 (1999)

4) (a) S. R. Dueker, Y. Lin, B. A. Buchholz, P. D. Schneider, M. W. Lame, H. J. Segall, J. S. Vogel \& A. J. Clifford: J. Lipid Res. 41, 1790-1800 (2000)

(b) B. A. Buchholz, A. Arjomand, S. R. Dueker, P. D. Schneider, A. J. Clifford \& J. S. Vogel: Anal. Biochem. 269, 348-352 (1999)

(c) A. J. Clifford, A. Arjomand, S. R. Dueker, P. D. Schneider, B. A. Buchholz \& J. S. Vogel: $A d v$. Exp. Med. Biol. 445, 239-251 (1998)

5) G. Shan, W. Huang, S. J. Gee, B. A. Buchholz, J. S. Vogel \& B. D. Hammock: Proc. Natl. Acad. Sci. USA 97, 24452449 (2000)

6) M. Miyashita, J. M. Presley, B. A. Buchholz, K. S. Lam, Y. M. Lee, J. S. Vogel \& B. D. Hammock: Proc. Natl. Acad. Sci. USA 98, 4403-4408 (2001)

7) J. S. Vogel, P. G. Grant, B. A. Buchholz, K. Dingley \& K W. Turteltaub: Electrophoresis 22, 2037-2045 (2001)

8) (a) B. J. Hughey, R. E. Klinkowstein, R. E. Shefer, P. L. Skipper, S. R. Tannenbaum \& J. S. Winshnok: Nucl. Instrum. Meth. Phys. Res. B 123, 153-158 (1997)

(b) D. J. W. Mous, K. H. Pueser, W. Fokker, R. van den Broek \& R. B. Koopmans: Nucl. Instrum. Meth. Phys Res. $B$ 123, 159-162 (1997) 